\title{
REVIEW
}

\section{Rhinovirus infections in infancy and early} childhood

\author{
Elisabeth Kieninger*, Oliver Fuchs*,\#, Philipp Latzin*, \\ Urs Frey ${ }^{\#}$ and Nicolas Regamey*
}

ABSTRACT: Rhinovirus (RV) infections occur early and recurrently in life, imposing a significant burden of disease on infants and young children. They are the most frequent causative agents of both upper and lower respiratory tract infections in this age group and are associated with a broad variety of clinical outcomes, ranging from asymptomatic infections to severe respiratory disease requiring hospitalisation. In addition to their impact on short-term morbidity, RVs are also debated as important pathogens in the development of recurrent wheeze and/or asthma. Several studies in infants at high-risk for atopy and asthma and in hospitalised children have demonstrated that recurrent wheezing illnesses induced by RVs early in life are a risk factor for the development of asthma later in childhood. However, underlying mechanisms are poorly understood. The question whether RVs are directly involved in the development of childhood wheeze and asthma, or whether symptomatic RV infections only represent a proxy for infants prone to develop obstructive lung diseases, is still open. In this review we provide an overview on the role of RVs as important disease-causing agents from infancy to early childhood and discuss their contribution to the subsequent development of childhood wheeze and/or asthma.

KEYWORDS: Asthma, development, infant, respiratory tract infection, virus, wheeze

cute respiratory tract infections (ARTIs) are the most frequent infections worldwide and represent a major public health problem. They are the leading cause of acute illnesses in all age groups and a major contributing factor of childhood morbidity and mortality [1,2]. Infants and young children are particularly vulnerable to ARTIs as their immunity is still developing and not fully in place to defend against most of the respiratory pathogens they are exposed to. ARTIs in young children are very common and usually of viral origin, due to the abundance of circulating viruses and their ease in transmission among hosts. Viral ARTIs in childhood result in a wide-range of disease severity; from the common cold to severe life-threatening respiratory tract infections [3]. Thus, they impose considerable burden on healthcare systems and account for a large proportion of emergency visits to hospital and hospitalisations [4].

A large number of community-based studies have characterised the frequency, seasonality, age specificity and clinical features of viral ARTIs in childhood and have determined which pathogens are most commonly involved with children [5-7]. These are the: respiratory syncytial virus (RSV) [8], influenza virus [9], parainfluenza virus [10], adenovirus [11], rhinovirus (RV) [12], and coronavirus [13]. Recent advances in the development of diagnostic techniques, and specifically of molecular biology tools [14-16], have led to the identification of additional viruses associated with ARTIs in childhood, amongst them are the human metapneumovirus [17], the coronaviruses NL63 and HKU1 [18, 19], bocavirus [20] and different subgroups of RVs [21], and of emerging viruses such as severe acute respiratory syndrome coronavirus [22] and the H5N1 and H1N1 influenza viruses [23, 24]. Whereas the role of RSV, influenza virus, parainfluenza virus, adenovirus and more recently the human metapneumovirus in causing ARTIs in infants and children have been intensively studied and are widely accepted $[6,25]$, the contribution of RVs to respiratory morbidity in childhood is subject to debate [26, 27].

The aim of this review is to provide an overview of the increasingly recognised role of RVs as important disease-causing agents from infancy to early childhood, to portray their impact on shortterm and long-term morbidity, and to depict their role in the development of childhood wheeze and asthma.

\section{AFFILIATIONS}

*Division of Respiratory Medicine, Dept of Paediatrics, University Children's Hospital of Bern, Inselspital, Bern, and \#University Children's Hospital (UKBB), University of Basel, Basel, Switzerland

CORRESPONDENCE

N. Regamey Division of Respiratory Medicine Dept of Paediatrics

University Children's Hospital of Bern Inselspital

3010 Bern Switzerland E-mail: Nicolas.Regamey@insel.ch

Received:

Nov 212011

Accepted after revision:

June 042012

First published online:

June 272012 


\section{CHARACTERISTICS, EPIDEMIOLOGY AND DETECTION OF RVs}

First discovered in the 1950s, RVs belong to the family Picornaviridae. They are small, non-enveloped viruses with a single-stranded, positive-sense RNA genome. To date, there are $>100$ identified serotypes, which are classified according to the receptor they bind to at the surface of the epithelial cells within the respiratory tract [28]. Strains binding to intercellular adhesion molecule (ICAM)-1 belong to the so-called majorgroup RVs, in contrast to the minor-group RVs, which consist of $\sim 10$ strains and bind to the low-density lipoprotein receptor [29]. According to sequence variations, RVs are further classified into two main phylogenetic species, RV-A and RV-B [30, 31]. Recently, a novel RV species distributed worldwide, namely RV-C, was identified [21, 32-35]. One of the striking characteristics of RVs when compared with many other respiratory viruses is that they replicate rapidly and demonstrate high mutation rates, resulting in distinct genetic diversity [36, 37]. Infections caused by certain genetic RV sublineages seem to be more prevalent in the general population, occurring during specific seasons, and are also more often associated with symptomatic respiratory diseases in children when compared to other sublineages [38, 39], e.g. $\mathrm{RV}-\mathrm{C}$ was shown to cause nearly half of all RV-induced ARTIs with clinical and age-related differences compared to RV-A or RV-B $[40,41]$.

The mode of RV transmission has been vividly discussed. Most probably, RVs are transmitted both by direct or indirect contact [28]. Infections caused by RVs have been shown to occur throughout the year $[42,43]$, but most reports suggest that there is a seasonal variability with peaks during cold and rainy seasons. The peak incidence of RV infections varies annually and geographically [44], most probably depending on the seasonal distribution of specific strains [45-47]. Compelling evidence shows higher rates of RV infections occurring during the crowding of children returning to school after their holidays [48-51]. Observations on virus transmission, infection patterns and immune responses suggest that due to a temporary lack of exposure during holidays, a transitory window of susceptibility to RV infections develops afterwards [52].

There are four principal ways in which RVs can be diagnosed: virus culture [53, 54], serology [53], immunofluorescence [55, 56] and nucleic acid/PCR-based tests [57]. Virus culture is labour-intensive and time-consuming procedure, and culture results may only be available when clinical symptoms have already disappeared. Serology, which has long been the main diagnostic tool for RV infections, relies on the detection of an immune response towards the virus and thus only provides a delayed and indirect picture of the infection itself. Further, serology is insensitive, as some RV serotypes lack a common group antigen, making the possibility of broadly reacting antibodies unlikely $[58,59]$. Therefore, it is no longer used in routine diagnostics, but only for study purposes, such as epidemiological studies aimed at following the natural course of an infection [57]. Due to the lack of sensitive detection methods, the prevalence of RV infections has been under estimated in early studies. The availability of new PCR-based molecular diagnostic techniques for the detection of viruses [60] has provided evidence that RVs are the leading agents of the common cold and wheezing illnesses in infants and young children compared to any other virus affecting the respiratory tract [61-67]. However, the high sensitivity of PCR is also a limitation, as the presence of virus nucleic acid in respiratory secretions of a patient with respiratory symptoms does not prove that the virus is the cause of the symptoms. PCR may overestimate RV burden because of a high proportion of positive results in asymptomatic children [64, 68-71]. Furthermore, PCR may detect remnants of previous viral infections or replication defective viral sequences. Indeed, the RV genome may be detected by PCR even weeks after an acute viral infection [65]. Finally, a high co-detection rate, with on average of $\sim 20 \%$ of respiratory samples being positive for two or more viruses during an ARTI [3, 72], adds to the difficulty of differentiating RVs as true pathogens from innocent bystanders. Due to its lower sensitivity, and possibly higher specificity for clinically relevant $\mathrm{RV}$ infections, rapid $\mathrm{RV}$ detection with immunfluorescence has been proposed as an alternative to PCR, both for clinical and research applications $[43,56,73,74]$.

\section{CLINICAL FEATURES OF RV INFECTIONS}

\section{RVs and their impact on short-term morbidity: upper respiratory tract infection and the "common cold"}

RVs are the most common pathogens associated with ARTIs in all age groups, and they account for the vast majority of upper respiratory tract infections (URTIs) [75-78]. Together with coronaviruses, they are the main causative agents of the common cold [44, 78]. The common cold is the colloquial expression for a self-limited URTI of a median duration of 910 days with the most prevalent symptoms being a runny nose, nasal stuffiness, sneezing, a sore throat and cough. Besides the common cold, RVs can also cause other URTIs with a range of mild to more-severe symptoms, such as acute otitis media, sinusitis, pharyngitis and croup $[4,78,79]$.

\section{RVs and their role in lower respiratory tract infections: more than just a "common cold"}

RVs replicate best at temperatures slightly below body temperature $\left(33-34^{\circ} \mathrm{C}\right)$ and, therefore, RV infections were long assumed to be restricted to the upper airways. Recent breakthroughs in molecular diagnostics have provided data on RVs as important causes of lower respiratory tract infections (LRTIs) and of acute virus-induced wheez in children. RVs were shown to have the capacity to infect the lower respiratory tract and to replicate effectively in lower airway cells even at core temperatures of $37^{\circ} \mathrm{C}$, although greater viral yields are obtained at lower temperatures [80-83]. In line with these findings, studies using sensitive molecular viral detection methods have shown that RVs are a common cause of LRTI in infants and young children; including wheezing disorders, bronchiolitis, and pneumonia with potential subsequent hospitalisations [65-67, 84-92]. Both prevalence and severity of LRTI induced by RVs are further increased in high-risk groups, especially in infants and young children with underlying chronic lung disease, such as those with bronchopulmonary dysplasia [93, 94], asthma [66, 90, 95, 96] and cystic fibrosis [97-101]. Co-infection with other viruses, mainly with RSV, occurs in approximately one-third of RV-infected children and has been linked to more severe respiratory symptoms [40, 86, 102, 103]. 


\section{RVs and their role in the very young}

Infections with RVs occur very early in life. Whereas older children experience on average one RV infection per year, this occurs up to two to three times more frequently in infants and younger children [42, 47]. As reported in several studies including in- and outpatient follow-up [47, 62-64, 67, 86, 87, 89, $90,92,104-107]$, as well as in prospective birth cohorts of otherwise healthy infants [66, 91, 108-111], RVs represent the most common pathogens associated with URTIs, LRTIs and wheeze in the first year of life (table 1). The mean age at the first symptomatic RV infection is 4-6 months compared with $>6$ months for other viruses, such as RSV $[67,91]$. By the age of 6 months, $>20 \%$ of children have already experienced their first RV infection, by the age of 2 yrs RVs can be identified in almost $80 \%$ of children with ARTIs, and $90 \%$ of children have antibodies against RVs [108]. Re-infections occur regularly and are usually caused by different viral strains [67]. Up to $30 \%$ of all hospitalisations due to respiratory symptoms in children $<5$ yrs of age are caused by RVs (this relates to five hospitalisations per 1,000 children) [90]. The highest incidence was found in children with a personal history of wheeze and/ or suspected asthma with up to $45 \%$, only second to RSV in children younger than 12 months of age $[62,86,87,89,106]$. At the same frequency, and especially among atopic infants older than 6 months, RV infections were found to be associated with ARTIs or wheeze $[66,107,110,112]$. This was also confirmed in studies from developing countries, which showed increased prevalence of RV infection and frequent association with wheeze in infants aged from 2-6 months [105, 111]. All these studies highlight the predominant role of RV as a respiratory pathogen in early life.

\section{RVS AND THEIR ROLE DURING ASTHMA DEVELOPMENT: CAUSING OR UNMASKING ASTHMA? Current evidence}

$\mathrm{RV}$ infections not only constitute the most common cause of acute illnesses and wheezing during infancy, but they have also been debated [113-116] as important pathogens with regard to the development of subsequent recurrent wheeze and asthma (table 2) [104, 110, 112, 117-121]. In the Childhood Origins of Asthma study, a birth cohort study of high-risk infants (where at least one parent had a history of doctordiagnosed hay fever, asthma or eczema), LEMANSKE et al. [112] and JACKSON et al. [110] identified moderate-to-severe RVinduced wheezing illnesses in the first years of life as the strongest predictors and risk factors for subsequent wheeze at the age of 3 yrs and 6 yrs, respectively. Almost $90 \%$ of highrisk children who wheezed with RVs at the age of 3 yrs had asthma at school age [110]. These findings are corroborated by data of an Australian birth cohort study of children at high risk for asthma development, in which KUSEL and co-workers [119, 120] found that RV-induced wheezing illnesses in infancy were associated with asthma at the age of 5 yrs and 10 yrs. Also Finnish studies $[117,118,121]$ showed that infants hospitalised because of RV-induced wheezing exhibited a considerably higher risk for childhood and adolescent asthma when compared with infants hospitalised because of LRTIs associated with other viruses. Taken together, high frequency and severe RV infections during infancy, especially in high-risk infants with an atopic background, seem to increase the risk for subsequent wheeze/asthma in childhood.

\section{Possible mechanisms}

The precise mechanisms through which RV-induced illnesses are involved in the pathogenesis of subsequent childhood wheeze and the development of asthma are unknown. Although the majority of children are infected with RV at the age of 2 yrs, only one-third of infants undergoing recurrent $\mathrm{RV}$-induced illnesses will go on to develop asthma later in life [28]. The question whether RV infections are directly involved in the development of childhood wheeze and asthma, for instance through damage of the airway epithelium and the induction of inflammatory and remodelling processes, or whether they unveil infants prone to developing obstructive lung diseases, is subject to debate [122]. In fact, both scenarios are not mutually exclusive.

As RVs have the ability to invade lower airways and escape immunity [58], they may promote exaggerated inflammatory responses towards further stimuli, such as allergens, and lead to enhanced airway responsiveness, possibly promoting the development of asthmatic features [123-126]. Evidence from animal studies further suggests that viral infections are important environmental stimuli for airway inflammation, injury and remodelling [126-128]. Infancy is a period of profound growth and development for the pulmonary and immune systems $[129,130]$, and recurrent RV infections and associated inflammatory and remodelling processes during this time may thus inter- and disrupt normal processes of lung growth. Infants repeatedly undergoing severe RV infections might, therefore, develop recurrent wheezing as a consequence of airway remodelling and impaired lung growth.

Alternatively, symptomatic RV infections might only represent a proxy for infants prone to developing obstructive lung diseases. Indeed, important determinants for the occurrence of wheezing illness including RV-associated wheezing during the first year of life have been recently described. An already reduced premorbid lung function shortly after birth was shown to predispose infants to more frequent and severe LRTIs [131-133]. Further studies have demonstrated that timing and frequency of RV-induced wheezing illnesses, respectively, play an important role in asthma pathogenesis [110, 134, 135]. The age at which RV-induced wheeze occurs has a prognostic value, with later wheeze playing a more important role than early wheeze [110, 112].

\section{Interplay with other risk factors for developing asthma}

Several risk factors for developing asthma, including non-viral risk factors, have been identified in clinical and populationbased studies.

Intrinsic factors include epigenetic $[136,137]$ and genetic factors [137-139], the stage of infant development, airway size [131-133, 138], immune function [138], male sex [138], stress [140], disease severity [120], airway hyperresponsiveness and atopic predisposition [138, 141-145]. Amongst extrinsic factors, environmental and lifestyle factors, such as various exposures in utero and in early life, e.g. indoor and outdoor air pollutants [138, 146, 147], environmental and parental/maternal tobacco smoke [138, 144, 148, 149], older siblings and early daycare attendance $[138,143]$ are known to be relevant. It has also been shown, for example, that traffic-related air pollution impairs lung development and influences the frequency of asthma exacerbations in 


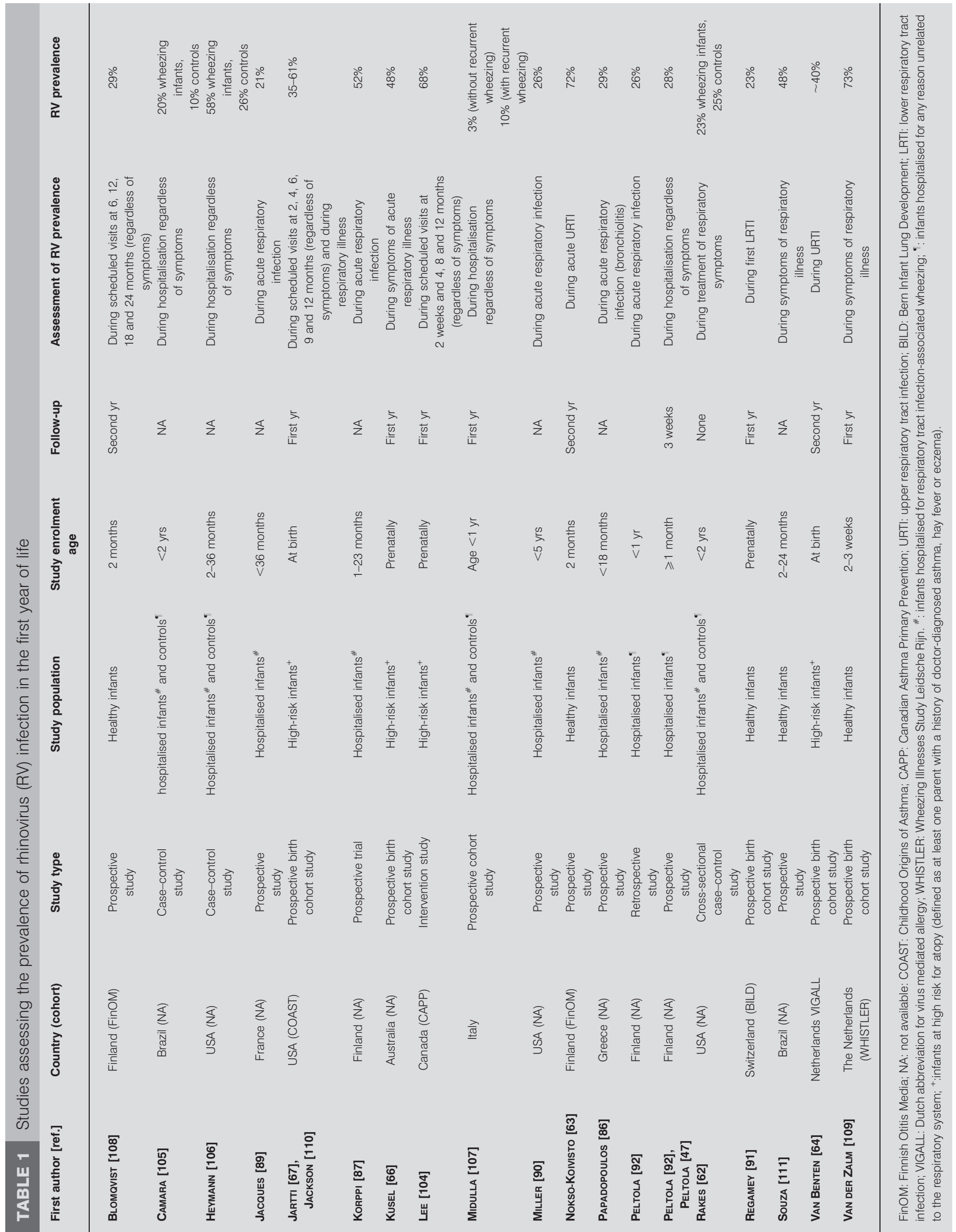




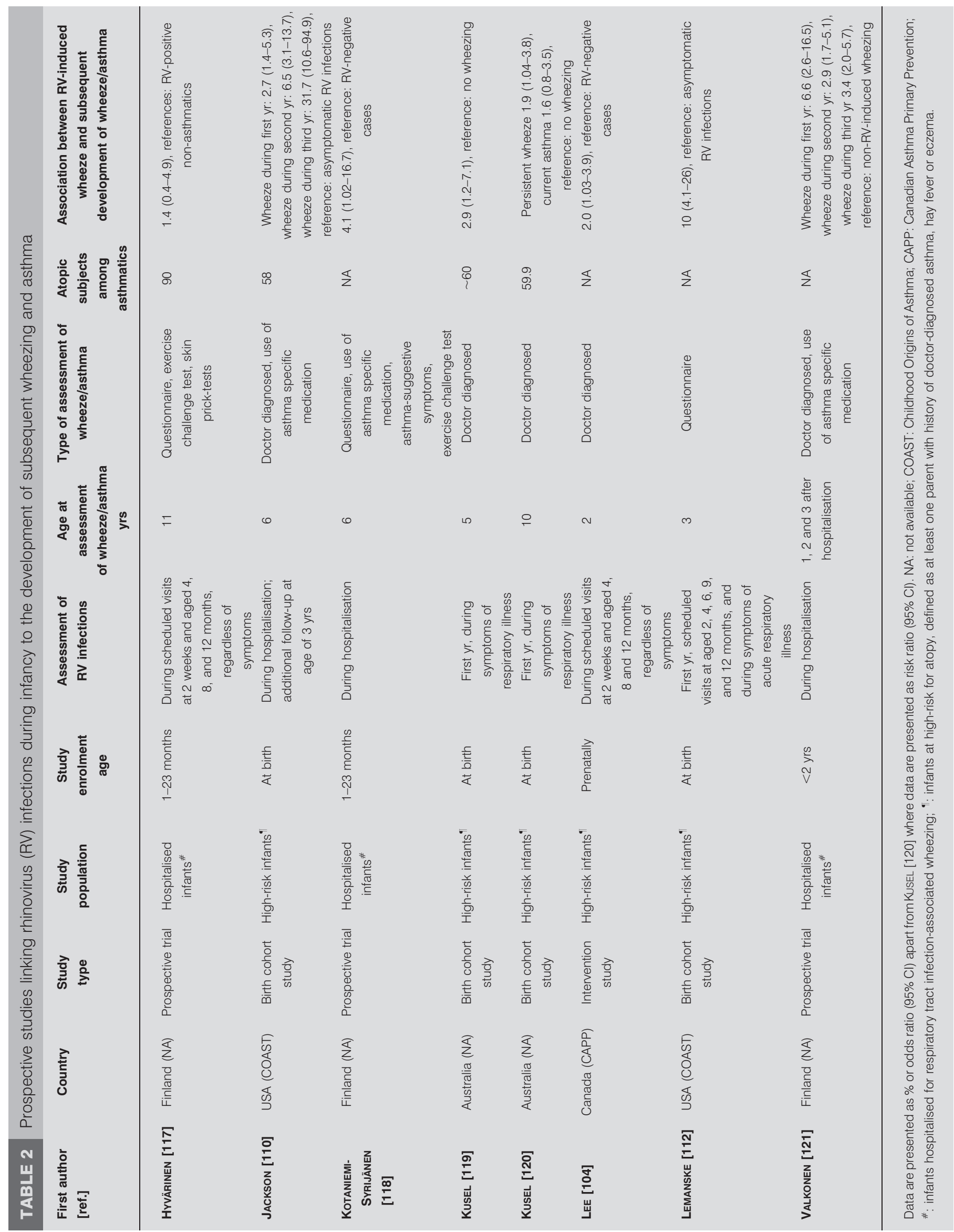


older children [150]. There is also evidence for a significant impact of air pollution and environmental tobacco smoke exposure on lung development during pregnancy and early life [151], with a clear connection to asthma development [150].

The interesting question is: which of these factors might denote a link to viral infections and their impact on asthma risk? One such factor is atopy. The highest risk to develop asthma was observed for children having both recurrent viral infections during infancy and atopic features, such as atopic dermatitis or a family history of allergy [110, 112, 119, 152, 153]. Moreover, it was recently demonstrated that allergic sensitisation precedes RV-associated wheezing [142], suggesting that allergic sensitisation leads to more severe RV-induced illnesses. These findings support a causal role for allergic sensitisation in this developmental pathway, but underlying mechanisms are poorly understood. It might be that the innate antiviral immune system of atopic children is additionally activated in an atopydependent way upon respiratory viral infections, which would amplify and sustain airway inflammation via enhancement of atopy-associated immune cascades, e.g. by increasing upregulation of specific high-affinity immunoglobulin E receptors involving T-helper type 2 cells $[145,154]$. Additional contributors and determinants of the risk might be polymorphisms in genes encoding cytokines or other mediators of the immune system [139], or genes that have been associated with asthma [155-158]. Some protective factors have been reported as well, in particular the allergy-protective farm exposure [159] and the presence of commensal bacteria [160]. Both factors are important for normal cellular immune maturation and further control of allergic airway inflammation. However, their role in preventing infants from RV-induced wheezing illnesses and further prevention of subsequent development of childhood asthma remains unclear. To summarise, viral aetiology, illness severity, timing, allergic sensitisation and genetic predisposition all probably contribute as synergistic factors to the risk of developing asthma.

\section{CONCLUSION AND OUTLOOK}

Recent advances in molecular diagnostic tools have led to an improved understanding of the impact of RV infections in infancy and childhood. RV infections occur early and recurrently in life and impose a large burden of disease on the very young. RVs are not only the most frequent pathogens of URTIs and LRTIs in this age group, but have been shown to represent an important pathogenic factor for the development of recurrent wheeze and asthma. However, most of the studies that have highlighted the role of RVs in causing acute illness and identified them as possible contributors in asthma development have involved hospitalised and high-risk infants or infants from selected populations with a wide age range. Thus, little is known about the true impact of RVs on both short- and long-term morbidity in otherwise healthy infants. In particular, knowledge concerning the occurrence of asymptomatic RV infections early in life and their relationship with for example early bacterial acquisition or atopy is poor. Carefully conducted prospective and longitudinal population-based studies in unselected healthy infants and young children are needed to more precisely define underlying mechanisms of RV-induced wheezing episodes in early life and their complex interactions with atopy, age and maturity of the immune system on asthma development. A better understanding and characterisation of these relationships might enable the identification and close follow-up of children who have a higher risk for severe RV infections and asthma development. This might also help to develop better preventive and therapeutic measures for these conditions, such as immunisations or antiviral therapies against RVs.

\section{STATEMENT OF INTEREST}

None declared.

\section{REFERENCES}

1 Williams BG, Gouws E, Boschi-Pinto C, et al. Estimates of worldwide distribution of child deaths from acute respiratory infections. Lancet Infect Dis 2002; 2: 25-32.

2 Mulholland K. Global burden of acute respiratory infections in children: implications for interventions. Pediatr Pulmonol 2003; 36: $469-474$

3 Tregoning JS, Schwarze J. Respiratory viral infections in infants: causes, clinical symptoms, virology, and immunology. Clin Microbiol Rev 2010; 23: 74-98.

4 Kesson AM. Respiratory virus infections. Paediatr Respir Rev 2007; 8: 240-248.

5 Badger GF, Dingle JH, Feller AE, et al. A study of illness in a group of Cleveland families. III. Introduction of respiratory infections into families. Am J Epidemiol 1953; 58: 41-46.

6 Monto AS. Epidemiology of viral respiratory infections. Am J Med 2002; 112: Suppl. 6A, 4S-12S.

7 Martinez FD. Viral infections and the development of asthma. Am J Respir Crit Care Med 1995; 151: 1644-1647.

8 Chanock RM, Kim HW, Vargosko AJ, et al. Respiratory syncytial virus. I. Virus recovery and other observations during 1960 outbreak of bronchiolitis, pneumonia, and minor respiratory diseases in children. JAMA 1961; 176: 647-653.

9 Izurieta HS, Thompson WW, Kramarz P, et al. Influenza and the rates of hospitalization for respiratory disease among infants and young children. N Engl J Med 2000; 342: 232-239.

10 Chanock RM, Parrott RH, Bell JA, et al. New viruses observed in children with respiratory diseases. Public Health Rep 1958; 73: 193-195.

11 Rowe WP, Huebner RJ, Gilmore LK, et al. Isolation of a cytopathogenic agent from human adenoids undergoing spontaneous degeneration in tissue culture. Proc Soc Exp Biol Med 1953; 84: 570-573.

12 Tyrrell DA, Parsons R. Some virus isolations from common colds. III. Cytopathic effects in tissue cultures. Lancet 1960; 1: 239-242.

13 Talbot HK, Crowe JE Jr, Edwards KM, et al. Coronavirus infection and hospitalizations for acute respiratory illness in young children. J Med Virol 2009; 81: 853-856.

14 Elnifro EM, Ashshi AM, Cooper RJ, et al. Multiplex PCR: optimization and application in diagnostic virology. Clin Microbiol Rev 2000; 13: 559-570.

15 Wang D, Coscoy L, Zylberberg M, et al. Microarray-based detection and genotyping of viral pathogens. Proc Natl Acad Sci USA 2002; 99: 15687-15692.

16 Garbino J, Gerbase MW, Wunderli W, et al. Lower respiratory viral illnesses: improved diagnosis by molecular methods and clinical impact. Am J Respir Crit Care Med 2004; 170: 1197-1203.

17 van den Hoogen BG, de Jong JC, Groen J, et al. A newly discovered human pneumovirus isolated from young children with respiratory tract disease. Nat Med 2001; 7: 719-724.

18 van der Hoek L, Pyrc K, Jebbink MF, et al. Identification of a new human coronavirus. Nat Med 2004; 10: 368-373. 
19 Woo PC, Lau SK, Chu CM, et al. Characterization and complete genome sequence of a novel coronavirus, coronavirus HKU1, from patients with pneumonia. J Virol 2005; 79: 884-895.

20 Allander T, Tammi MT, Eriksson M, et al. Cloning of a human parvovirus by molecular screening of respiratory tract samples. Proc Natl Acad Sci USA 2005; 102: 12891-12896.

21 Lee WM, Kiesner C, Pappas $\mathrm{T}$, et al. A diverse group of previously unrecognized human rhinoviruses are common causes of respiratory illnesses in infants. PLoS One 2007; 2: e966.

22 Peiris JS, Guan Y, Yuen KY. Severe acute respiratory syndrome. Nat Med 2004; 10: Suppl. 12, S88-S97.

23 Abdel-Ghafar AN, Chotpitayasunondh T, Gao Z, et al. Update on avian influenza A (H5N1) virus infection in humans. $N$ Engl J Med 2008; 358: 261-273.

24 Dawood FS, Jain S, Finelli L, et al. Emergence of a novel swineorigin influenza A (H1N1) virus in humans. N Engl J Med 2009; 360: 2605-2615.

25 Pavia AT. Viral infections of the lower respiratory tract: old viruses, new viruses, and the role of diagnosis. Clin Infect Dis 2011; 52: Suppl. 4, S284-S289.

26 Hershenson MB, Johnston SL. Rhinovirus infections: more than a common cold. Am J Respir Crit Care Med 2006; 174: 1284-1285.

27 Regamey N, Kaiser L. Rhinovirus infections in infants: is respiratory syncytial virus ready for the challenge? Eur Respir $J$ 2008; 32: 249-251.

28 Gern JE. The ABCs of rhinoviruses, wheezing, and asthma. J Virol 2010; 84: 7418-7426.

29 Vlasak M, Blomqvist S, Hovi T, et al. Sequence and structure of human rhinoviruses reveal the basis of receptor discrimination. J Virol 2003; 77: 6923-6930.

30 Savolainen C, Blomqvist S, Mulders MN, et al. Genetic clustering of all 102 human rhinovirus prototype strains: serotype 87 is close to human enterovirus 70. J Gen Virol 2002; 83: 333-340.

31 Ledford RM, Patel NR, Demenczuk TM, et al. VP1 sequencing of all human rhinovirus serotypes: insights into genus phylogeny and susceptibility to antiviral capsid-binding compounds. J Virol 2004; 78: 3663-3674.

32 Lau SK, Yip CC, Tsoi HW, et al. Clinical features and complete genome characterization of a distinct human rhinovirus (HRV) genetic cluster, probably representing a previously undetected HRV species, HRV-C, associated with acute respiratory illness in children. J Clin Microbiol 2007; 45: 3655-3664.

33 McErlean P, Shackelton LA, Lambert SB, et al. Characterisation of a newly identified human rhinovirus, HRV-QPM, discovered in infants with bronchiolitis. J Clin Virol 2007; 39: 67-75.

34 McErlean P, Shackelton LA, Andrews E, et al. Distinguishing molecular features and clinical characteristics of a putative new rhinovirus species, human rhinovirus $\mathrm{C}$ (HRV C). PLoS One 2008; 3: e1847.

35 Miller EK, Khuri-Bulos N, Williams JV, et al. Human rhinovirus $\mathrm{C}$ associated with wheezing in hospitalised children in the Middle East. J Clin Virol 2009; 46: 85-89.

36 Crotty S, Andino R. Implications of high RNA virus mutation rates: lethal mutagenesis and the antiviral drug ribavirin. Microbes Infect 2002; 4: 1301-1307.

37 Poland GA, Barry MA. Common cold, uncommon variation. N Engl J Med 2009; 360: 2245-2246.

38 Arden KE, McErlean P, Nissen MD, et al. Frequent detection of human rhinoviruses., paramyxoviruses, coronaviruses, and bocavirus during acute respiratory tract infections. I Med Virol 2006; 78: 1232-1240.

39 van der Zalm MM, Wilbrink B, van Ewijk BE, et al. Highly frequent infections with human rhinovirus in healthy young children: a longitudinal cohort study. J Clin Virol 2011; 52: $317-320$
40 Miller EK, Edwards KM, Weinberg GA, et al. A novel group of rhinoviruses is associated with asthma hospitalizations. J Allergy Clin Immunol 2009; 123: 98-104.e1.

41 Iwane MK, Prill MM, Lu X, et al. Human rhinovirus species associated with hospitalizations for acute respiratory illness in young US children. J Infect Dis 2011; 204: 1702-1710.

42 Gwaltney JM Jr, Hendley JO, Simon G, et al. Rhinovirus infections in an industrial population. I. The occurrence of illness. N Engl J Med 1966; 275: 1261-1268.

43 Sadeghi CD, Aebi C, Gorgievski-Hrisoho M, et al. Twelve years' detection of respiratory viruses by immunofluorescence in hospitalised children: impact of the introduction of a new respiratory picornavirus assay. BMC Infect Dis 2011; 11: 41.

44 Heikkinen T, Jarvinen A. The common cold. Lancet 2003; 361: 51-59.

45 Fox JP, Cooney MK, Hall CE, et al. Rhinoviruses in Seattle families, 1975-1979. Am J Epidemiol 1985; 122: 830-846.

46 Monto AS, Bryan ER, Ohmit S. Rhinovirus infections in Tecumseh, Michigan: frequency of illness and number of serotypes. J Infect Dis 1987; 156: 43-49.

47 Peltola V, Waris M, Osterback R, et al. Clinical effects of rhinovirus infections. J Clin Virol 2008; 43: 411-414.

48 Lincoln D, Morgan G, Sheppeard V, et al. Childhood asthma and return to school in Sydney, Australia. Public Health 2006; 120: 854-862.

49 Sears MR, Johnston NW. Understanding the September asthma epidemic. J Allergy Clin Immunol 2007; 120: 526-529.

50 Silverman RA, Ito K, Stevenson L, et al. The relationship of fall school opening and emergency department asthma visits in a large metropolitan area. Arch Pediatr Adolesc Med 2005; 159: 818-823.

51 Storr J, Lenney W. School holidays and admissions with asthma. Arch Dis Child 1989; 64: 103-107.

52 Tovey ER, Rawlinson WD. A modern miasma hypothesis and back-to-school asthma exacerbations. Med Hypotheses 2011; 76: 113-116.

53 Laboratory diagnosis of viral disease. In: White DO, Fenner FJ, eds. Medical Virology 4th Edn. San Diego, Academic Press; 1997; pp. 198-217.

54 Leland DS, Ginocchio CC. Role of cell culture for virus detection in the age of technology. Clin Microbiol Rev 2007; 20: 49-78.

55 Mackie PL, Joannidis PA, Beattie J. Evaluation of an acute pointof-care system screening for respiratory syncytial virus infection. 1 Hosp Infect 2001; 48: 66-71.

56 Schindera C, Kraemer AL, Regamey N, et al. Immunofluorescence versus xTAG multiplex PCR for the detection of respiratory picornavirus infections in children. J Clin Virol 2010; 48: 223-225.

57 Mahony JB. Detection of respiratory viruses by molecular methods. Clin Microbiol Rev 2008; 21: 716-747.

58 Niespodziana K, Napora K, Cabauatan C, et al. Misdirected antibody responses against an $\mathrm{N}$-terminal epitope on human rhinovirus VP1 as explanation for recurrent RV infections. FASEB J 2012; 26: 1001-1008.

59 Smith TJ. Antibody interactions with rhinovirus: lessons for mechanisms of neutralization and the role of immunity in viral evolution. Curr Top Microbiol Immunol 2001; 260: 1-28.

60 Caliendo AM. Multiplex PCR and emerging technologies for the detection of respiratory pathogens. Clin Infect Dis 2011; 52: Suppl. 4, S326-S330.

61 Johnston SL, Sanderson G, Pattemore PK, et al. Use of polymerase chain reaction for diagnosis of picornavirus infection in subjects with and without respiratory symptoms. J Clin Microbiol 1993; 31: 111-117.

62 Rakes GP, Arruda E, Ingram JM, et al. Rhinovirus and respiratory syncytial virus in wheezing children requiring 
emergency care: IgE and eosinophil analyses. Am J Respir Crit Care Med 1999; 159: 785-90.

63 Nokso-Koivisto J, Pitkäranta A, Blomqvist S, et al. Viral etiology of frequently recurring respiratory tract infections in children. Clin Infect Dis 2002; 35: 540-546.

64 van Benten I, Koopman L, Niesters B, et al. Predominance of rhinovirus in the nose of symptomatic and asymptomatic infants. Pediatr Allergy Immunol 2003; 14: 363-370.

65 Jartti T, Lehtinen P, Vuorinen T, et al. Persistence of rhinovirus and enterovirus RNA after acute respiratory illness in children. J Med Virol 2004; 72: 695-699.

66 Kusel MM, de Klerk NH, Holt PG, et al. Role of respiratory viruses in acute upper and lower respiratory tract illness in the first year of life: a birth cohort study. Pediatr Infect Dis J 2006; 25: 680-686.

67 Jartti T, Lee WM, Pappas T, et al. Serial viral infections in infants with recurrent respiratory illnesses. Eur Respir J 2008; 32: 314-320.

68 Nokso-Koivisto J, Kinnari TJ, Lindahl P, et al. Human picornavirus and coronavirus RNA in nasopharynx of children without concurrent respiratory symptoms. J Med Virol 2002; 66: 417-420.

69 van Gageldonk-Lafeber AB, Heijnen ML, Bartelds AI, et al. A case-control study of acute respiratory tract infection in general practice patients in The Netherlands. Clin Infect Dis 2005; 41: 490-497.

70 van der Zalm MM, van Ewijk BE, Wilbrink B, et al. Respiratory pathogens in children with and without respiratory symptoms. J Pediatr 2009; 154: 396-400.e1.

71 Jansen RR, Wieringa J, Koekkoek SM, et al. Frequent detection of respiratory viruses without symptoms: toward defining clinically relevant cutoff values. J Clin Microbiol 2011; 49: 2631-2636.

72 Weigl JA, Puppe W, Meyer CU, et al. Ten years' experience with year-round active surveillance of up to 19 respiratory pathogens in children. Eur J Pediatr 2007; 166: 957-966.

73 Madeley CR, Peiris JS. Methods in virus diagnosis: immunofluorescence revisited. J Clin Virol 2002; 25: 121-134.

74 Barbani MT, Gorgievski-Hrisoho M. Rapid detection of respiratory picornaviruses in nasopharyngeal aspirates by immunofluorescence assay. J Clin Virol 2009; 45: 245-248.

75 Monto AS, Sullivan KM. Acute respiratory illness in the community. Frequency of illness and the agents involved. Epidemiol Infect 1993; 110: 145-160.

76 Arruda E, Pitkaranta A, Witek TJ Jr., et al. Frequency and natural history of rhinovirus infections in adults during autumn. J Clin Microbiol 1997; 35: 2864-2868.

77 Makela MJ, Puhakka T, Ruuskanen O, et al. Viruses and bacteria in the etiology of the common cold. J Clin Micriobiol 1998; 36: $539-42$.

78 Mackay IM. Human rhinoviruses: the cold wars resume. J Clin Virol 2008; 42: 297-320.

79 Winther B. Rhinovirus infections in the upper airway. Proc Am Thorac Soc 2011; 8: 79-89.

80 Gern JE, Galagan DM, Jarjour NN, et al. Detection of rhinovirus RNA in lower airway cells during experimentally induced infection. Am J Respir Crit Care Med 1997; 155: 1159-1161.

81 Papadopoulos NG, Bates PJ, Bardin PG, et al. Rhinoviruses infect the lower airways. J Infect Dis 2000; 181: 1875-1884.

82 Mosser AG, Vrtis R, Burchell L, et al. Quantitative and qualitative analysis of rhinovirus infection in bronchial tissues. Am J Respir Crit Care Med 2005; 171: 645-651.

83 Brownlee JW, Turner RB. New developments in the epidemiology and clinical spectrum of rhinovirus infections. Curr Opin Pediatr 2008; 20: 67-71.

84 Juven T, Mertsola J, Waris M, et al. Etiology of communityacquired pneumonia in 254 hospitalized children. Pediatr Infect Dis J 2000; 19: 293-298.
85 Malcolm E, Arruda E, Hayden FG, et al. Clinical features of patients with acute respiratory illness and rhinovirus in their bronchoalveolar lavages. J Clin Virol 2001; 21: 9-16.

86 Papadopoulos NG, Moustaki M, Tsolia M, et al. Association of rhinovirus infection with increased disease severity in acute bronchiolitis. Am J Respir Crit Care Med 2002; 165: 1285-1289.

87 Korppi M, Kotaniemi-Syrjanen A, Waris M, et al. Rhinovirusassociated wheezing in infancy: comparison with respiratory syncytial virus bronchiolitis. Pediatr Infect Dis J 2004; 23: 995-999.

88 Pitrez PM, Stein RT, Stuermer L, et al. Bronquiolite aguda por rinovirus em lactentes jovens [Rhinovirus and acute bronchiolitis in young infants]. J Pediatr (Rio J) 2005; 81: 417-420.

89 Jacques J, Bouscambert-Duchamp M, Moret H, et al. Association of respiratory picornaviruses with acute bronchiolitis in French infants. J Clin Virol 2006; 35: 463-466.

90 Miller EK, Lu X, Erdman DD, et al. Rhinovirus-associated hospitalizations in young children. J Infect Dis 2007; 195: 773-781.

91 Regamey N, Kaiser L, Roiha HL, et al. Viral etiology of acute respiratory infections with cough in infancy: a community-based birth cohort study. Pediatr Infect Dis J 2008; 27: 100-105.

92 Peltola V, Jartti T, Putto-Laurila A, et al. Rhinovirus infections in children: a retrospective and prospective hospital-based study. J Med Virol 2009; 81: 1831-1838.

93 Chidekel AS, Bazzy AR, Rosen CL. Rhinovirus infection associated with severe lower respiratory tract illness and worsening lung disease in infants with bronchopulmonary dysplasia. Pediatr Pulmonol 1994; 18: 261-263.

94 Chidekel AS, Rosen CL, Bazzy AR. Rhinovirus infection associated with serious lower respiratory illness in patients with bronchopulmonary dysplasia. Pediatr Infect Dis J 1997; 16: 43-47.

95 Johnston SL, Pattemore PK, Sanderson G, et al. Community study of role of viral infections in exacerbations of asthma in 9-11 year old children. BMJ 1995; 310: 1225-1229.

96 Kling S, Donninger H, Williams Z, et al. Persistence of rhinovirus RNA after asthma exacerbation in children. Clin Exp Allergy 2005; 35: 672-678.

97 Wang EE, Prober CG, Manson B, et al. Association of respiratory viral infections with pulmonary deterioration in patients with cystic fibrosis. N Engl J Med 1984; 311: 1653-1658.

98 Ramsey BW, Gore EJ, Smith AL, et al. The effect of respiratory viral infections on patients with cystic fibrosis. Am J Dis Child 1989; 143: 662-668.

99 Collinson J, Nicholson KG, Cancio E, et al. Effects of upper respiratory tract infections in patients with cystic fibrosis. Thorax 1996; 51: 1115-1122.

100 Hiatt PW, Grace SC, Kozinetz CA, et al. Effects of viral lower respiratory tract infection on lung function in infants with cystic fibrosis. Pediatrics 1999; 103: 619-626.

101 van Ewijk BE, van der Zalm MM, Wolfs TF, et al. Prevalence and impact of respiratory viral infections in young children with cystic fibrosis: prospective cohort study. Pediatrics 2008; 122: 1171-1176.

102 Aberle JH, Aberle SW, Pracher E, et al. Single versus dual respiratory virus infections in hospitalized infants: impact on clinical course of disease and interferon- $\gamma$ response. Pediatr Infect Dis J 2005; 24: 605-610.

103 Franz A, Adams O, Willems R, et al. Correlation of viral load of respiratory pathogens and co-infections with disease severity in children hospitalized for lower respiratory tract infection. J Clin Virol 2010; 48: 239-245.

104 Lee KK, Hegele RG, Manfreda J, et al. Relationship of early childhood viral exposures to respiratory symptoms, onset of possible asthma and atopy in high risk children: the Canadian Asthma Primary Prevention Study. Pediatr Pulmonol 2007; 42: 290-297.

105 Camara AA, Silva JM, Ferriani VP, et al. Risk factors for wheezing in a subtropical environment: role of respiratory 
viruses and allergen sensitization. J Allergy Clin Immunol 2004; 113: 551-557.

106 Heymann PW, Carper HT, Murphy DD, et al. Viral infections in relation to age, atopy, and season of admission among children hospitalized for wheezing. J Allergy Clin Immunol 2004; 114: 239-247.

107 Midulla F, Pierangeli A, Cangiano G, et al. Rhinovirus bronchiolitis and recurrent wheezing: 1-year follow-up. Eur Respir J 2012; 39: 396-402.

108 Blomqvist S, Roivainen M, Puhakka T, et al. Virological and serological analysis of rhinovirus infections during the first two years of life in a cohort of children. J Med Virol 2002; 66 : 263-268.

109 van der Zalm MM, Uiterwaal CS, Wilbrink B, et al. Respiratory pathogens in respiratory tract illnesses during the first year of life: a birth cohort study. Pediatr Infect Dis J 2009; 28: 472-476.

110 Jackson DJ, Gangnon RE, Evans MD, et al. Wheezing rhinovirus illnesses in early life predict asthma development in high-risk children. Am J Respir Crit Care Med 2008; 178: 667-672.

111 Souza LS, Ramos EA, Carvalho FM, et al. Viral respiratory infections in young children attending day care in urban Northeast Brazil. Pediatr Pulmonol 2003; 35: 184-191.

112 Lemanske RF Jr, Jackson DJ, Gangnon RE, et al. Rhinovirus illnesses during infancy predict subsequent childhood wheezing. J Allergy Clin Immunol 2005; 116: 571-577.

113 Gern JE. Rhinovirus and the initiation of asthma. Curr Opin Allergy Clin Immunol 2009; 9: 73-78.

114 Holgate ST. Rhinoviruses in the pathogenesis of asthma: the bronchial epithelium as a major disease target. J Allergy Clin Immunol 2006; 118: 587-590.

115 Jackson DJ. The role of rhinovirus infections in the development of early childhood asthma. Curr Opin Allergy Clin Immunol 2010; 10: $133-138$.

116 Sly PD, Kusel M, Holt PG. Do early-life viral infections cause asthma? J Allergy Clin Immunol 2010; 125: 1202-1205.

117 Hyvärinen MK, Kotaniemi-Syrjanen A, Reijonen TM, et al. Teenage asthma after severe early childhood wheezing: an 11year prospective follow-up. Pediatric Pulmonol 2005; 40: 316-323.

118 Kotaniemi-Syrjänen A, Vainionpaa R, Reijonen TM, et al. Rhinovirus-induced wheezing in infancy - the first sign of childhood asthma? J Allergy Clin Immunol 2003; 111: 66-71.

119 Kusel MM, de Klerk NH, Kebadze T, et al. Early-life respiratory viral infections, atopic sensitization, and risk of subsequent development of persistent asthma. J Allergy Clin Immunol 2007; 119: $1105-1110$.

120 Kusel MM, Kebadze T, Johnston SL, et al. Febrile respiratory illnesses in infancy and atopy are risk factors for persistent asthma and wheeze. Eur Respir J 2012; 39: 876-882.

121 Valkonen $\mathrm{H}$, Waris M, Ruohola A, et al. Recurrent wheezing after respiratory syncytial virus or non-respiratory syncytial virus bronchiolitis in infancy: a 3-year follow-up. Allergy 2009; 64: 1359-1365.

122 Sly PD, Boner AL, Björksten B, et al. Early identification of atopy in the prediction of persistent asthma in children. Lancet 2008; 372: $1100-1106$

123 Lemanske RF Jr, Dick EC, Swenson CA, et al. Rhinovirus upper respiratory infection increases airway hyperreactivity and late asthmatic reactions. J Clin Invest 1989; 83: 1-10.

124 Leigh R, Oyelusi W, Wiehler S, et al. Human rhinovirus infection enhances airway epithelial cell production of growth factors involved in airway remodeling. J Allergy Clin Immunol 2008; 121: 1238-1245.

125 Proud D, Turner RB, Winther B, et al. Gene expression profiles during in vivo human rhinovirus infection: insights into the host response. Am J Respir Crit Care Med 2008; 178: 962-968.
126 Schneider D, Hong JY, Popova AP, et al. Neonatal rhinovirus infection induces mucous metaplasia and airways hyperresponsiveness. J Immunol 2012; 188: 2894-2904.

127 Nagarkar DR, Bowman ER, Schneider D, et al. Rhinovirus infection of allergen-sensitized and -challenged mice induces eotaxin release from functionally polarized macrophages. J Immunol 2010; 185: 2525-2535.

128 Bartlett NW, Walton RP, Edwards MR, et al. Mouse models of rhinovirus-induced disease and exacerbation of allergic airway inflammation. Nat Med 2008; 14: 199-204.

129 Dezateux C, Stocks J. Lung development and early origins of childhood respiratory illness. Br Med Bull 1997; 53: 40-57.

130 Gern JE, Rosenthal LA, Sorkness RL, et al. Effects of viral respiratory infections on lung development and childhood asthma. J Allergy Clin Immunol 2005; 115: 668-674.

131 Martinez FD, Morgan WJ, Wright AL, et al. Diminished lung function as a predisposing factor for wheezing respiratory illness in infants. N Engl J Med 1988; 319: 1112-1117.

132 Martinez FD, Morgan WJ, Wright AL, et al. Initial airway function is a risk factor for recurrent wheezing respiratory illnesses during the first three years of life. Group Health Medical Associates. Am Rev Respir Dis 1991; 143: 312-316.

133 van der Zalm MM, Uiterwaal CS, Wilbrink B, et al. The influence of neonatal lung function on rhinovirus-associated wheeze. Am J Respir Crit Care Med 2011; 183: 262-267.

134 Illi S, von Mutius E, Lau S, et al. Early childhood infectious diseases and the development of asthma up to school age: a birth cohort study. BMJ 2001; 322: 390-395.

$135 \mathrm{Wu}$ P, Dupont WD, Griffin MR, et al. Evidence of a causal role of winter virus infection during infancy in early childhood asthma. Am J Respir Crit Care Med 2008; 178: 1123-1129.

136 Adcock IM, Tsaprouni L, Bhavsar P, et al. Epigenetic regulation of airway inflammation. Curr Opin Immunol 2007; 19: 694-700.

137 Singh AM, Moore PE, Gern JE, et al. Bronchiolitis to asthma: a review and call for studies of gene-virus interactions in asthma causation. Am J Respir Crit Care Med 2007; 175: 108-119.

138 Taussig LM, Wright AL, Holberg CJ, et al. Tucson Children's Respiratory Study: 1980 to present. J Allergy Clin Immunol 2003; 111: 661-675.

139 Helminen M, Nuolivirta K, Virta M, et al. IL-10 gene polymorphism at $-1082 \mathrm{~A} / \mathrm{G}$ is associated with severe rhinovirus bronchiolitis in infants. Pediatr Pulmonol 2008; 43: 391-395.

140 Cohen S. Psychological stress and susceptibility to upper respiratory infections. Am J Respir Crit Care Med 1995; 152: S53-S58.

141 Palmer LJ, Rye PJ, Gibson NA, et al. Airway responsiveness in early infancy predicts asthma, lung function, and respiratory symptoms by school age. Am J Respir Crit Care Med 2001; 163: $37-42$.

142 Jackson DJ, Evans MD, Gangnon RE, et al. Evidence for a causal relationship between allergic sensitization and rhinovirus wheezing in early life. Am J Respir Crit Care Med 2012; 185: 281-285.

143 Koopman LP, Smit HA, Heijnen ML, et al. Respiratory infections in infants: interaction of parental allergy, child care, and siblings- The PIAMA study. Pediatrics 2001; 108: 943-948.

144 Holt PG, Sly PD. Viral infections and atopy in asthma pathogenesis: new rationales for asthma prevention and treatment. Nat Med 2012; 18: 726-735.

145 Kotaniemi-Syrjanen A, Reijonen TM, Korhonen $\mathrm{K}$, et al. Wheezing due to rhinovirus infection in infancy: Bronchial hyperresponsiveness at school age. Pediatr Int 2008; 50: 506-510.

146 Brauer M, Hoek G, Van Vliet $P$, et al. Air pollution from traffic and the development of respiratory infections and asthmatic and allergic symptoms in children. Am J Respir Crit Care Med 2002; 166: 1092-1098. 
147 Latzin $\mathrm{P}$, Röösli M, Huss A, et al. Air pollution during pregnancy and lung function in newborns: a birth cohort study. Eur Respir J 2009; 33: 594-603.

148 Martinez FD, Wright AL, Taussig LM, et al. Asthma and wheezing in the first six years of life. The Group Health Medical Associates. N Engl J Med 1995; 332: 133-138.

149 Stick SM, Burton PR, Gurrin L, et al. Effects of maternal smoking during pregnancy and a family history of asthma on respiratory function in newborn infants. Lancet 1996; 348: 1060-1064.

150 Salam MT, Islam T, Gilliland FD. Recent evidence for adverse effects of residential proximity to traffic sources on asthma. Curr Opin Pulm Med 2008; 14: 3-8.

151 Gilliland FD, Berhane K, McConnell R, et al. Maternal smoking during pregnancy, environmental tobacco smoke exposure and childhood lung function. Thorax 2000; 55: 271-276.

152 Oddy WH, de Klerk NH, Sly PD, et al. The effects of respiratory infections, atopy, and breastfeeding on childhood asthma. Eur Respir J 2002; 19: 899-905.

153 Holt PG, Upham JW, Sly PD. Contemporaneous maturation of immunologic and respiratory functions during early childhood: implications for development of asthma prevention strategies. J Allergy Clin Immunol 2005; 116: 16-24.
154 Subrata LS, Bizzintino J, Mamessier E, et al. Interactions between innate antiviral and atopic immunoinflammatory pathways precipitate and sustain asthma exacerbations in children. J Immunol 2009; 183: 2793-2800.

155 Van Eerdewegh P, Little RD, Dupuis J, et al. Association of the ADAM33 gene with asthma and bronchial hyperresponsiveness. Nature 2002; 418: 426-430.

156 Moffatt MF, Kabesch M, Liang L, et al. Genetic variants regulating ORMDL3 expression contribute to the risk of childhood asthma. Nature 2007; 448: 470-473.

157 Bartlett NW, McLean GR, Chang YS, et al. Genetics and epidemiology: asthma and infection. Curr Opin Allergy Clin Immunol 2009; 9: 395-400.

158 Moffatt MF, Gut IG, Demenais F, et al. A large-scale., consortiumbased genomewide association study of asthma. $N$ Engl J Med 2010; 363: 1211-1221.

159 von Mutius E, Vercelli D. Farm living: effects on childhood asthma and allergy. Nat Rev Immunol 2010; 10: 861-868.

160 Herbst T, Sichelstiel A, Schar C, et al. Dysregulation of allergic airway inflammation in the absence of microbial colonization. Am J Respir Crit Care Med 2011; 184: 198-205. 